\title{
Model of The Social Capital Based Community Entrepreneurship Education (CCE) For Empowering Community: A Initial Theoretical Perspective
}

\author{
Entoh Tohani \\ Nonformal Education Department \\ Yogyakarta State University, Indonesia \\ Corresponding e-mail: tohani@uny.ac.id
}

\begin{abstract}
This paper seeks to examine social capital in community entrepreneurship education (CCE) in the context of community economic empowerment. The importance of social capital is utilized in the implementation of community entrepreneurship education due to CCE nowadays many of which are implemented more dominated by educational paradigs oriented to the development of human capital. Another thing is through the implementation of CCE expected social capital can develop in an effort to promote society. It is hoped that in the future, the implementation of entrepreneurship education of society based on social capital can realize the entrepreneurship that is able to develop themselves and their society effectively and accountably. Therefore, to implement it, required a pure commitment from all parties related to the implementation of this education either at the micro level, meso, and macro.
\end{abstract}

Keywords: $\quad$ social capital; entrepreneurship; education; model

\section{INTRODUCTION}

Economic development of a society is basically intended to improve the quality of life and the lives of citizens through increased income to meet the needs of its economy. Every society has different policies and developments in economic development. Porter, et al. (2002) stated that economic development can be distinguished in three specific stages: (a) factor-driven stage, (b) effeciency-driven stage, and (c) innovation-driven stage (1). Factor-driven stage is an economic development based on the utilization of natural and human resources, which still generate low income. Effeciency-driven stage is characterized by the production of services and goods that are standardized and economic activities in this stage is more inclined to the manufacture and export activities. While the innovation-driven stage is characterized by the ability to produce goods and services more innovative by using the latest technology. In the last stage, entrepreneurship is one of the factors causing the economic development of society and entrepreneurship is possible to be more developed due to technological changes during the period of world war, and the decline in the manufacturing sector.

In Indonesian society, the development of entrepreneurial activities of the community as a driver of economic development seems less encouraging. A survey conducted by General Entrepreneurship Monitor (GEM) in 2014 positioned Indonesia as a country that still emphasizes on economic development based more on the efficiency of economic development process (2). Indonesia is a country whose economic development uses the availability of technology, develope education and training at universities to create labor, and focuses on the efficiency of the product market, the labor market, and market size. That is, Indonesia is still minimal in growing and developing entrepreneurial activities in society both related to the development of entrepreneurial attitudes, entrepreneurial activities, and social culture for entrepreneurship.

This condition is reinforced by several studies that emphasize that entrepreneurship education in Indonesia has not been optimally developed and still prioritize the formation of human capital. The fact from those findings that show non-formal education programs for the poor with life skills stop at the dimensions of learning output even though the learning organization is already running (3), the entrepreneurial learning process that has the target group of adults in the countryside (4), and entrepreneurial learning for high school students dominant emphasizes on establishment mastery of the entrepreneurial skills and spirit especially in economic business fields (5), community entrepreneurship education managed by the community with the support of government funding meet some obstacles which includes lack of capital, equipment is still simple, marketing is not maximal, and human resources are not good quality and quantity (6), and also establishment of the business centers for the development of entrepreneurship is still not yet optimal (7).

Nevertheless, entrepreneurship development has been and continues to be done by various parties by organizing community entrepreneurship education 
(CCE) that is expected to produce entrepreneurs who are able to produce goods and / or services that are beneficial to the advancement of life itself and the environment. In this case, CCE should be able to form an individual or group that was originally only as a potential entrepreneur, becoming a nascent entrepreneur, and becoming a new business owner, and eventually becoming a business owner already developed. The formation of individuals who eventually have a well-established or advanced business needs to be done by providing various learning experiences and providing educational facilitation that enables them to apply the value, knowledge and skills of entrepreneurship they have, along with the provision of adequate facilities. The establishment of a competent entrepreneur becomes an important task that needs to be done by entrepreneurship education providers by organizing meaningful learning process of entrepreneurship.

One way is to organize this education in the future that is based on empowering and developing social capital in order to produce progress of target groups both individuals and communities in order to create a just and prosperous life and contribute to the success of future education and community progress.

\section{ENTREPRENEURSHIP EDUCATION}

Education is interpreted as a conscious effort to develop individuals, groups, and communities in order to have the values, skills, and knowledge useful to get a better life. One of the goals of education is to make people have the capacity to engage in creative activities, create their own business, or work for the company in the context of fulfilling their needs which includes primary needs, personal needs, social needs, etc. This means that education has to enable individuals have entrepreneurship competencies as Drucker (1985) states that entrepreneurial capacity can be built on education (8). In other words, entrepreneurship education will be a means or tool for creating human resources to develop the economic and welfare system of society.

Theoretically, CCE is a form of entrepreneurship education that is specifically intended for citizens who are generally adults and / or marginalized groups. Fayolle \& Gailly (2008) proposes an entrepreneurship education model that is divided into two levels, namely the ontological level and the educational process level (9). The ontological level describes three aspects of the education: what is the meaning of entrepreneurship education, what is the meaning of education in context of the entrepreneurship, and the role of educators and learners. CCE is understood as a process to develop target groups (individuals or groups) into creative, innovative and productive people who are able to find solutions to problems encountered using resources in their environment in both social and natural resources. It arises because of uncertain social change and demands entrepreneurial competence owned by individuals, organizations and society (10). Increasing entrepreneurship education needs can be attributed to: (a) demand of economic development, job creation, expansion of economic networks, technological change and political climate change, as well as emergence of innovation, (b) learners have the opportunity to work independently or self-employment and obtain professional careers in any company of any size, and (c) large or medium-sized companies are demanding their staff to be able to belong to new managerial skills and behaviors (11).

At the educational level, this education has interrelated aspects, namely (a) the goal of entrepreneurship education, (b) the target group, (c) curriculum, (d) educational methods, (e) implementation of the educational process, and (f) evaluation. Purpose of the education describe a situation is planned and expected to be achieved, which it the realization of entrepreneurial competence that includes: cognitive competencies, social competencies, and action-oriented competencies (12). In line with this, Fayolle (2008) argues that entrepreneurship education has three goals categories: raising student awareness, teaching techniques, procedures and problem solving, and supporting projects as mutual companies. Another thought is debated by Mwasalwiba (2010) which suggests that the specific goals of entrepreneurship education can be grouped into learning "about", learning "for", learning "through", and learning "in", as well as service programs to society (13).

The implementation of CCE is expected to be carried out effectively which is an increase of prosperity to individuals, groups and communities. In this case, the target group must be able to make the learning outcomes that have been achieved to be meaningful for kehidupannnya. Learning outcomes which sould be achieved not only as something that is not useful or innerts idea, but applied in the form of productive entrepreneurial activities in everyday life both individually and in groups. Productive activities must be able to provide material and economic benefits to them. Further the results of applying the learning outcomes should be directed to the development of a positive social role of the target group on community life such as acting as a community developer and community educator, and enhancing positive contributions to political life particularly in participation of development and decision making in facing the problems faced together. In brief, CEE must be means to produce productivity, adaptability, and continuity.

$\mathrm{CCE}$ is organized for establishing entrepreneurial competence in the target groups to be productive individuals that can produce quality improvement of their life welfare, especially in the 
economic field. The level of achievement of the objectives and quality of CCE is highly dependent on the utilization of its capitals. One of them which is important is social capital which can be forms: network, norm, rule, commitment, information and trust. Social capital is a potential that enables target groups to effectively develop their entrepreneurial activities.

The definition of social capital itself is quite diverse proposed by experts in accordance with their respective points of view. For example, Coleman explains that social capital consists of two elements: (a) social capital is an aspect of a social structure, and (b) social capital facilitates the actions of individuals in the structure, social capital is both real and potential resources achieved from a relationship (14) (15). Putnam (1994:167) states that social capital is a characteristic of social life ie networks, norms, and beliefs that enable individuals to behave together effectively to achieve common goals. It is productive, making possible the achievement of certain ends that would not be attainable in its absence (16). While Nahapiet \& Ghosal (1998) details more about the dimensions or aspects of social capital. Social capital has three dimensions: structural, relation, and cognition (17). The dimension of the structure includes the mechanism of the relationship between principals. From this understanding it can be put forward that social capital is a useful potential and woke up because of an intense social relationship.

Particularly in the context of community economic development, it is defined as the goodwill available to individuals or groups. Its source lies in the structure and content of the social relation of actors. Its effects flow from the information, influence, and solidarity it makes available to the actor (18). Social capital is a goodwill available to individuals or organizations. The source of social capital lies in the structure and content of the social relations of the principals. The impact is information, influence, and solidarity which makes it useful to actors. According to this expert, on social structure there are social relationships of actors that can includes: hierarchy / power relationships, social life relationships, and business relationships. Of course, these relationships contains opportunities for the perpetrator to acquire the existing resources within the social structure.

Weslund (2006) considers that social capital is something that should be used in the promotion of business or entrepreneurship activities (19). He explained social capital is an asset needed in business development, where social capital is able to generate economic benefits. In this case, social capital can be distinguished by its function namely: (a) it could be related to the internal life of business institutions such as the existence of values, norms and habits that support the spirit of the company, organizational climate, knowledge management, (b) it could be related to production processes such as relationships or networks with suppliers, users of products, and partners in the enterprise and development, (c) it could be related to the environment, especially local environment relations, relations with policy makers, and relationships with non-business organizations, and (d) other one linked to markets that include relationships with consumers built on product marketing, customer organizations, etc.

As the concept of capital, social capital has differences and similarities with other forms of capital. Westlund \& Bolton (2003) show both in terms of productivity, vintages, accumulation and maintenance, ownership, and complexity (20) as in Table 1 below.

Table 1. Similarities and differences in social capital with other capital

\begin{tabular}{|c|c|}
\hline Similirities & Differences \\
\hline \multicolumn{2}{|c|}{ Productivity } \\
\hline \multicolumn{2}{|l|}{$\begin{array}{l}\text { Social capital is an } \\
\text { invisible cost that may } \\
\text { become obsolete }\end{array}$} \\
\hline $\begin{array}{l}\text { Social capital can be } \\
\text { used for good or bad }\end{array}$ & $\begin{array}{c}\text { Social capital states the interests } \\
\text { of the actors, good or bad from a } \\
\text { community perspective. Social } \\
\text { capital is not neutral to the views } \\
\text { of society. }\end{array}$ \\
\hline \multicolumn{2}{|r|}{ Vintages } \\
\hline $\begin{array}{l}\text { Social capital consists } \\
\text { of vintages }\end{array}$ & $\begin{array}{l}\text { The result (vintage) of social } \\
\text { capital is proportional to one port } \\
\text { wine compared to other forms of } \\
\text { capital. The vintage composition } \\
\text { determines. There is no } \\
\text { correlation between age and } \\
\text { decreased productivity. }\end{array}$ \\
\hline \multicolumn{2}{|c|}{ Accumulation and maintance } \\
\hline $\begin{array}{l}\text { Social capital can be } \\
\text { damaged if it is not } \\
\text { maintained }\end{array}$ & $\begin{array}{l}\text { Social capital is a product of both } \\
\text { the conscious investment and the } \\
\text { unintentional product of the } \\
\text { actions of others }\end{array}$ \\
\hline $\begin{array}{c}\text { Social capital is a result } \\
\text { of past actions }\end{array}$ & $\begin{array}{c}\text { The accumulation of social } \\
\text { capital does not necessarily } \\
\text { require deliberate sacrifice for } \\
\text { future gain }\end{array}$ \\
\hline & $\begin{array}{l}\text { Social capital is more difficult to } \\
\text { wake up through external } \\
\text { intervention }\end{array}$ \\
\hline \multicolumn{2}{|c|}{ Private vs public goods } \\
\hline \multicolumn{2}{|l|}{$\begin{array}{l}\text { Access to social capital } \\
\text { never belongs to the } \\
\text { public completely. } \\
\text { Access requires } \\
\text { connections for a } \\
\text { particular network and } \\
\text { / or skills }\end{array}$} \\
\hline \multicolumn{2}{|c|}{ Complexity and level of aggregation } \\
\hline \multirow[t]{2}{*}{$\begin{array}{l}\text { Diverse social capital } \\
\text { means less vulnerable } \\
\text { to changes in economic } \\
\text { structure }\end{array}$} & $\begin{array}{l}\text { Social capital is the most } \\
\text { diversified, less homogeneous } \\
\text { form of capital }\end{array}$ \\
\hline & $\begin{array}{c}\text { The merging of different social } \\
\text { capital faces major } \\
\text { methodological difficulties }\end{array}$ \\
\hline
\end{tabular}




\section{MODEL OF THE CCE BASED ON SOCIAL CAPITAL}

One can be a successful entrepreneur determined by the extent to which human capital and social capital it has, especially in an increasingly complex and rapidly changing environment. According to Neace (1999) human capital that exists in the entrepreneur includes the ability to be visionary, confident, knowledgeable, ambitious, has charisma, and possesses the skills / experiences, and social capital that contributes to the success of the entrepreneur could be forms association owned, organizational and interpersonal trust, mediating networks, and users and disseminators (21). The human capital of the entrepreneur has been an important factor in its success, but this is not enough. This means that social capital may be a determining factor because entrepreneurial skills are useless if the individual who owns them does not build positive interactions with other individuals such as Peterseon \& Ronsdstadt (1986) stated that successful entrepreneurship is knowing new ideas, knowing "how" and supplemented by knowing "who" (22).

Entrepreneurs must have social capital as one of the competence of an entrepreneur (23) because it is primarily formed from relationships with others (external) contributes to the success of a business actor, as Figure 1. Social capital affects the formation of an innovative capacity of an entrepreneur In which the resulting innovation can bring benefits or rewards for itself such as access to information, strength, and awakening solidarity as well as for the community such as information diffusion, task completion assistance for social welfare, created civil society.

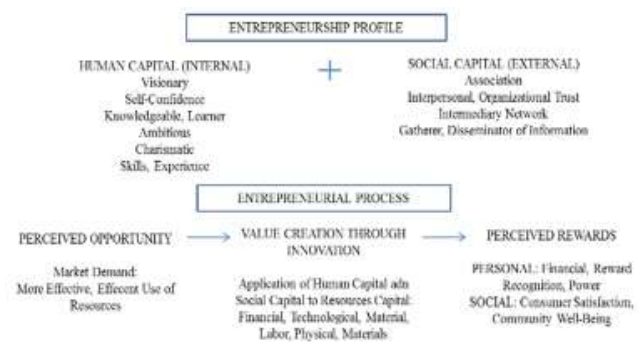

Figure 1. Social capital competency of entrepreneur

As an educative effort to realize successful entrepreneurs, CEE needs to be organized with an approach that is oriented towards the utilization and development of social capital. This educational process should be directed to the mastery and development of the social capital competencies of entrepreurs that includes: internalization of values, norms, and positive commitment in developing the business, built trust ability, enlarge network ability, and develope ability of information and / or knowledge management. Consequently, the future model of social capital-based entrepreneurship education can be implemented so that these capabilities can be understood, internalized, used, and developed in a constructive learning process in terms of input, process, output and outcome as well as CEE management activities in order to develop the target groups to be more empowered both individually, family, and society.

CEE development oriented to the content of social capital can be formulated with reference to the input-process-product-outcomes aspects as presented in Chart 1. The CEE that will be developed in the future can be implemented:

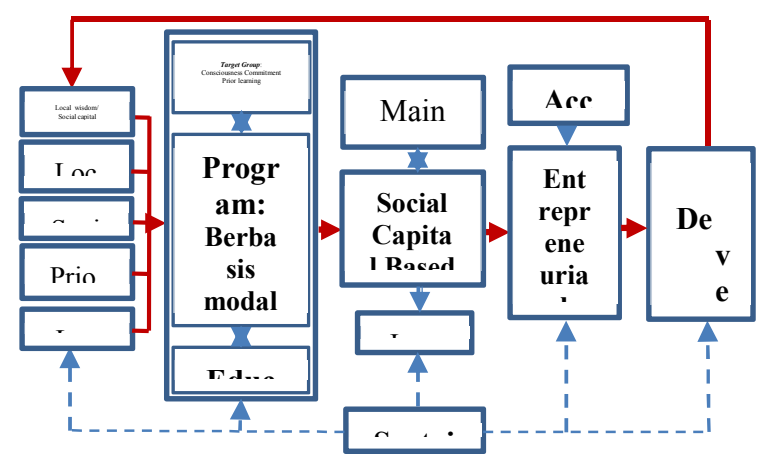

Figure 2. Model of The Social Capital Based Community Entrepreneurship Education.

The model of education shows that the education process that will be done by educators or agents of change have characterstics includes:

(a) Based on assessment and understanding of the context affecting the target group includes local wisdom, national, regional and local economic policies, socio-cultural life, existing issues, local leadership and embryos of entrepreneurial or other economic activities;

(b) Determining the right target group and viewing the level of awareness, commitment, and learning experience they have;

(c) The CCE program is more dominantly oriented towards network capacity development, ability to build trust, ability to communicate and to build organizational capacity;

(d) The learning process is conducted by prioritizing a social capital based, experiencebased, and cooperative approach, complemented by the availability of business incubators and supported by partnerships with other business actors;

(e) Learning outcomes are directed at the establishment of entrepreneurship skills applied in life both individually and in groups, and the target group is expected to form a group of joint ventures;

(f) Furthermore, it is expected to realize the economic progress, social capital development process, and development of community 
practices that can provide benefits to the business actors; and

(g) To ensure success, the implementation of entrepreneurship education needs to be done by developing sustaine evaluation activities.

\section{CONCLUSION}

Implementation of CCE will not work well if it develops substance which solely emphasize the formation of quality individuals who have functional or technical capability of entrepreneurship. Therefore, CCE held needs to be carried out by prioritizing the development of entrepreneurship skills that have two dimensions: (a) the development of entrepreneurship skills as a form of human capital formation, and (b) the ability of social capitaloriented qualified to enable target groups to quickly apply the learning outcomes and obtain benefits he expected. The existence of CCE development based on the utilization and development of social capital will easily guarantee the success of community development as well as to increase the participation of the relevant parties in order to advance the target group and / or the community. The development of the quality of the target group of CCE as such hopes needs to be balanced with an educational process that puts forward the educational process based on shared values of trust, commitment, and humanist learning.

Implementation of the CCE based on social capital development is an constructive effort that requires great support and commitment from each related party. Great commitment is a necessary prerequisite whereby this may indicate that awakened awareness and shared desire are manifested in participatory behavior in the implementation of this education. Another thing is that in context of the community empowerment, community entrepreneurship learning needs to be done by prioritizing the formation of empowerment networks that indicate there is pure involvement of all parties involved in education both at micro, meso and macro level. That is, the learning process or empowerment is done not just on the technical readiness in running the lesson plans for the community, but based on the perpetrators of empowerment who have high commitment accompanied with the ability or capacity it has.

\section{REFERENCES}

[1] Adles PS\&KWS. Social capital: Prospect for a new Concept. The Academy of Management Review. 2002 January ; 27(1): p. 17-40.

[2] Singer SAJE,\&MAD. Global Entrepreneurship Monitori 2014 Global Report. London:; 2015.

[3] Suryono Y\&TE. Evaluasi Program Pendidikan Nonformal Berbasis Pendidikan Kecakapan Hidup dalam Mengatasi Kemiskinan. Penelitian dan Evaluasi Pendidikan. 2010; 2: p. 249-265.
[4] Yudi. Model Kreatif Pembelajaran P4 pada Pendidikan Kecakapan Hidup Produksi Jamur Merang. Jurnal Ilmiah VISI PTK-PNF. 2010; 5: p. 77-93.

[5] Hasanah. Pengembangan Model Pembelajaran Kewirausahaan untuk Pembentukan Jiwa Entrepreneur Siswa di Sekolah Menengah Kejurusan. Disertation. Universitas Negeri Yogyakarta; 2011.

[6] Fakhrudin ea. Strategi Pengembangan Kewirausahaan Masyarakat Semarang: Widya Karya; 2012.

[7] Suryono Yd. Pembelajaran Kewirausahaan Masyarakat Yogyakarta: Aditya Media; 2012.

[8] Drucker PF. Innovation and Entrepreneurship California: Perfect Bound; 1984.

[9] Fayolle A. Handbook of Research in Entrepreneurship Education Vol. 2 Contextual Perspective New York: Cambridge University Press; 2007.

[10] Kirby DA. Entrepreneurship Education: Can Business Schools Met The Challenge? Journal Education + Training. 2004; 46: p. 510-519.

[11] Fayolle A. Handbook of Research in Entrepreneurship Education, Vol. 2 Contextual Perpectives Northampton: Edward Elgar; 2007.

[12] Boyless T. 21st Century Knowledge, Skills, and Abilities adn Competencies: A Model For Undergraduate Entrepreneurship Education. Journal of Entrepreneurship Education. 2012; 15: p. 41-45.

[13] Mwasalwiba ES. Entrepreneurship Education: A Review of Its Objectives, Teaching Methods, and Impact Indicators. Education + Training. 2010; 52: p. 20-47.

[14] Coleman JS. Social Capital in The Creation of Human capital. American Journal of Sociology. 1988; 94: p. S94-S120.

[15]Lin N. Social Capital: A Theory of Structure Social and Action Cambridge: Cambridge University Press; 2004.

[16] Putnam R. Making Democracy Work: Civic Tradition in Modern Italy New Jersey: Princeton University Press; 1993.

[17] Nahapiet J\&GS. Social Capital, Intellectual Capital, and the Organizational Advantage. The Academy of Management Review. 1998 April; 23(2): p. 242-266.

[18] Adler PS\&KWS. Social Capital: Prospect for A New Concept. The Academic of Management Review. 2002 January; 27(1): p. 17-40.

[19] Weslund H. Social Capital in The Knowledge Economy Ostersund: Springer-Verlag Berlin Heidelberg; 2006.

[20] Weslund H\&BR. Local Social Capital and EntrepreneurshipSpecial Issue on 
Entrepreneurship, Firm Growth and Regional Development in the New Economic Geography. Small Business Economics. 2003 September; 21(2).

[21] Neace MB. Entrepreneurship in Emergin Economics: Creating Trust, Social Capital, and Civil Society. Annals of The American Academy of Political and Social Science. 1999 September; 565: p. 148-161.

[22] Bridge S. Reflections on The Omission of The Social Capital from Enterprise Education and Business Start Training. Education + Training. 2013; 55(8/9): p. 899-910.
[23] Neace MB. Enterpreneurship in Emerging Economies: Creating Trust, Social Capital, and Civil Society. Annals of The American Academy of Political adn Social Science. 1999 September; 564: p. 148-161. 